\title{
Energy-saving and by-products-free production of ethanol from granular corn starch
}

\author{
DARIA SZYMANOWSKA*, WŁODZIMIERZ GRAJEK \\ Department of Biotechnology and Food Microbiology, Poznań University of Life Sciences, Poznań, Poland \\ *Corresponding author: darszy@up.poznan.pl
}

\begin{abstract}
Intense development of the transport sector and a rise in the prices of fossil fuels boost the demand for fuels from alternative sources of energy, including biofuels. Thus, new energy-efficient technologies of fuel production from renewable resources are being developed. Accordingly, we attempted to create a technology of bioethanol production by simultaneous enzymatic hydrolysis and fermentation of native corn starch. In our work we used commercially available STARGEN 001 enzymatic preparation for native corn starch hydrolyzis, and yeast Saccharomyces cerevisiae strain Red Star Ethanol Red for it's fermentation. A major part of the research was on developing a fermentation technology with repeated full recirculation of stillage liquid fraction. It has been shown that a completely effluentless ethanol production with separation of stillage solid fraction and using the liquid fraction to prepare the next portion of corn mash is possible. Thus the process can proceed for several months without any effluent.
\end{abstract}

Key words: ethanol, simultaneous saccharification and fermentation, stillage, recycling

\section{Introduction}

The technologies of biological ethanol production have been known for a long time. So far they have been based on the process of initial starch processing which requires liquefaction of starch at high temperature to obtain a starch solution. This generates high energy consumption, usually amounting to about $30-40 \%$ of all energy needed for ethanol production (Lim et al., 2003). In order to reduce the costs, there is constant pursuit of energy-efficient technologies that ensure high productivity. A possible solution is one-step method of ethanol production by simultaneous hydrolysis and fermentation in one reactor - SSF, Simultaneous Saccharification and Fermentation (Bednarski and Reps, 2003; Öhgren et al., 2007) using the enzymes that can hydrolyze native starch and prevent its gelatinization In this method, the products of hydrolysis are immediately used by microorganisms. Consequently, the enzymes inhibition is limited and ethanol productivity is higher by $25-40 \%$ in comparison to the traditional two-step method. Additionally, a one-step method eliminates the need of using two separate tanks (cost reduction) and theoretically reduces the length of the process by excluding the time of pre- liminary fermentation that occurs already during hydrolysis (Kobayashi et al., 1998). Since the process of hydrolysis occurs in higher temperatures than fermentation numerous projects are focused on finding the enzymes which are active at lower temperature or thermotolerant microorganisms that have the enzymes which can both ferment and hydrolyze a given substrate. The optimal temperature of glucoamylase and $\alpha$-amylase activity is about $60^{\circ} \mathrm{C}$, while most of distiller's yeast strains have the growth optimum of $30-32^{\circ} \mathrm{C}$. In the process of simultaneous saccharification and fermentation, the optimal temperature of a medium is the highest that distiller's yeast can withstand. Thus, the temperature of this process usually fluctuates around $35^{\circ} \mathrm{C}$, which is actually a compromise between the optimum temperature of enzyme activity and the yeast growth.

In addition, using native corn starch in the SSF process will enable considerable reduction of the costs of heating starch mashes. Generally it is assumed that native starch (in the form of non-gelatinized granules) is resistant to hydrolysis by amylolytic enzymes. However, owing to the progress in molecular biology in the last few years, a commercial enzymatic preparation has come 
on the market, that exhibits amylolytic activity to native starch. It is STARGEN 001 developed by Genencor International. STARGEN 001 preparation is used for hydrolysis of native starch to fermenting sugars. It catalyzes the depolymerization of polysaccharides to glucose, hence it can be applied in the process of simultaneous hydrolysis of native starch and ethanol fermentation. STARGEN 001 allows to eliminate double $\mathrm{pH}$ regulation (liquefaction step - optimum $\mathrm{pH}=5.0-6.0$, saccharification step - optimum $\mathrm{pH}=4.8-5.0)$. Furthermore, in the use of STARGEN 001 there are no limitations related to the viscosity of mashes, so mediums of high density can be used in the process. Employing STARGEN 001 results in higher ethanol productivity obtained by avoiding the loss of fermenting sugars, which may occur during heating (the Maillard reaction), and ensures energy and water saving. Additionally, it does not require using an activator, such as calcium ions for most of amylases.

Additionally, studies in which the effectiveness of the processes of saccharification and fermentation in one (SSF) and in two tanks (SHF - Separate Hydrolisis and Fermentation) were compared on a bench scale with the use of steam-pretreated corn stover, proved the advantage of the SSF process due to the reduction of enzyme inhibition (Öhgren et al., 2007). It should be emphasized that the SSF process is described in the literature also with respect to the second-generation bioethanol production (Thomsen et al., 2008; Erdei et al., 2010). Thomsen et al. (2008) assessed the process of ethanol production from corn silage by the SSF method preceded by high-temperature pretreatment of the raw material. The highest yield obtained by these authors was $37 \mathrm{~g}$ of ethanol / 1 of corn silage. Other authors (Shanavas et al., 2011), who examined the process of simultaneous hydrolysis of cassava starch (using STARGEN 001 preparation) and ethanol fermentation, obtained ethanol efficiency of $295.20 \mathrm{~g} / \mathrm{kg}$ of starch.It should also be mentioned that most published studies that describe research on the SSF process, do not concern native starch. The stage of hydrolysis and fermentation is often preceded with high-temperature treatment of the raw material (Wang et al., 2005; Nikolic et al., 2009; Shanavas et al., 2011).

Modern microbial biosynthesis technologies should ensure not only a high product yield, but also take into account the problem of environmental pollution. In ethanol fermentation using yeast, the main waste product is stillage (Decloux et al., 2002). The volumetric proportion of stillage to the amount of ethanol obtained is about 13:1 (Madejon et al., 2001). A medium-sized distillery manufacturing $50 \mathrm{~m}^{3}$ of alcohol per day produces stillage in quantities of about $650 \mathrm{~m}^{3}$ daily. Stillage is considered to be a highly polluting waste and its utilization is difficult and costly. Stillage has a high water content (91-95\%) and high values of COD (chemical oxygen demand) and BOD (biochemical oxygen demand) $\left(60-100 \mathrm{~g} \mathrm{O}_{2} / \mathrm{dm}^{3}\right)$ (Fitzgibbon et al., 1995). Therefore a major part of the research was on developing a fermentation technology with repeated full recirculation of stillage liquid fraction.

The aim of the present study was to develop a modern technology of ethanol production from corn flour with omitting gelatinization and liquefaction by using enzymes digesting native corn starch. This technology should involve the simultaneous saccharification of native starch and ethanol fermentation combined with recirculation of stillage liquid fraction.

\section{Materials and methods \\ Raw material}

Commercially available corn flour (BIO CORN, Ziębice, Poland) was used as the raw material for fermentation. It had a median diameter of $250 \mu \mathrm{m}$, and contained $12.8 \%$ of water, $84.7 \%$ of starch, and $0.1 \%$ of ash.

\section{Yeast}

Freeze-dried distiller's yeast, Red Star Ethanol Red (Saccharomyces cerevisiae), obtained from Lesaffre Company (Marcq en Baroeul, France) was used in this study for the production of ethanol from corn mashes. The number of the living cells at packing was $>2.0 \times 10^{10} / \mathrm{g}$, as defined by the manufacturer.

\section{Enzymes}

A mixture of granular starch hydrolyzing enzymes, containing Aspergillus kawachi $\alpha$-amylase expressed in Trichoderma reesei, and glucoamylase from Aspergillus niger were employed in this study (STARGEN 001, Genencore International, USA). The enzymatic activity of this set of enzymes was $\geq 456 \mathrm{GSHU} / \mathrm{g}$ (Granular Starch Hydrolyzing Units), as defined by Genencore International. In addition, the fungal acid protease GC 106 ( $A s$ pergillus niger), also obtained from Genencore International, was added to the mashes. The enzymatic activity of GC 106 was $\geq 1000$ SAPU/g (Spectrophotometric Acid Protease Units), as defined by the manufacturer. 


\section{Simultaneous saccharification and fermentation}

The SSF experiments were performed in 51 bioreactor BioFlo III (New Brunswick, USA) containing 41 of the fermentation medium. A weighed amount of corn flour was suspended in unsterilized water. The $\mathrm{pH}$ of the fermentation broth was measured and adjusted to 5.0 by the addition of either $10 \% \mathrm{H}_{2} \mathrm{SO}_{4}$ or $20 \% \mathrm{NaOH}$. In all cases, the medium was supplemented with the acid protease GC 106 ( $40 \mu \mathrm{l} / \mathrm{kg}$ corn flour dry matter) and STARGEN 001 (2.05 ml/kg corn flour dry matter). The fermentation was started with the addition of freeze-dried distiller's yeast Red Star Ethanol Red $(0.5 \mathrm{~g} / 1$ of the fermentation medium). After the inoculation the number of the living cells in the medium was $1.0 \times 10^{7}$ cells $/ \mathrm{ml}$. The repeated batch SSF fermentations were performed in anaerobic non-sterile conditions at $35^{\circ} \mathrm{C}$ with medium agitation rate of $200 \mathrm{rpm}$ for $72 \mathrm{~h}$. The samples were taken and analyzed for yeast cell viability as well as for starch, glucose and ethanol concentrations after the fermentation. The bacterial contamination in the mash was avoided by the addition of $50 \mu \mathrm{g} / \mathrm{ml}$ chloramphenicol. All the experiments were performed in triplicate.

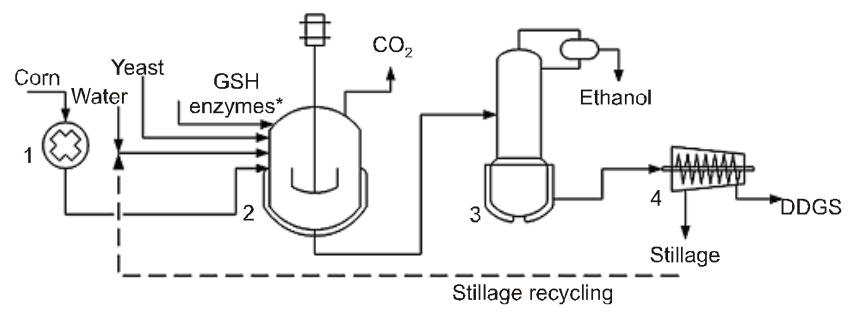

Fig. 1. Simultaneous saccharification and fermentation process of raw starch using GSH enzymes: 1) hammer mill, 2) fermentor, 3) distillation column, 4) decanter, DDGS - Dried Distillers Grains with solubles

\section{Recycling of stillage}

After the fermentation period was completed, mash containing ethanol was pumped to a continuous distillation column (UOP3CC, Armfield, UK). At the top of this column, operating at $78.5^{\circ} \mathrm{C}$ and reflux ratio of $4: 1$, ethanol concentrated to $93-95 \%$ (volume based) is collected in a side stream. The liquid fraction collected at the bottom of the distillation column, was first cooled down to $30^{\circ} \mathrm{C}$ and then centrifuged at $4000 \mathrm{~g}$ for $20 \mathrm{~min}$. Supernatant was used instead of water for dilution of native corn starch for next SSF run. The recirculation of stillage was performed at constant recirculation degree, $75 \%$ of fresh water was replaced by stillage. The proce- dure was repeated twenty times over a period of 60 days, using a fresh yeast culture for inoculation on each run.

\section{Analysis}

Samples for the analysis of glucose and ethanol concentrations were firstly centrifuged at $4000 \mathrm{~g}$ for $10 \mathrm{~min}$. at $4{ }^{\circ} \mathrm{C}$ (Multifuge 3SR, Germany), filtered through a $0.22 \mu \mathrm{m}$ membrane filter (Millex-GS, Millipore, USA), and then analyzed on an HPLC system (Merck Hitachi, Germany). Glucose and ethanol were separated on an Aminex HPX-87P (Bio-Rad, USA) at $30^{\circ} \mathrm{C}$ using $5 \mathrm{mM}$ $\mathrm{H}_{2} \mathrm{SO}_{4}$ solution as the mobile phase at the flow rate of $0.6 \mathrm{ml} / \mathrm{min}$, and detected with a refractive index detector (Model L-7490, Merck Hitachi, Germany). The starch content was analyzed according to the enzymatic method developed by Holm et al. (1986). The yeast cell populations were determined by a direct microscopic count in a counting chamber after staining with methylene blue.

\section{Results and Discussion}

The process of fed-batch simultaneous saccharification of native corn starch and ethanol fermentation (SSF)

In the conducted research, the previously experimentally determined optimal conditions of the SSF process were applied: the dose of STARGEN 001 enzymatic preparation of $2.05 \mathrm{ml}$ per kilogram of flour dry matter, environmental $\mathrm{pH} 5.0$ and $25 \%(\mathrm{w} / \mathrm{v})$ concentration of starch mash (Białas et al., 2009).

In order to verify the optimal conditions of SSF and assess its kinetic parameters, the process of simultaneous saccharification of native starch and ethanol fermentation in 51 bioreactors was performed. The results presented in Figure 2 show that the SSF process ran correctly. Together with the formation of starch hydrolysis products, the mash ethanol concentration was increasing. After 72 hours, the efficiency amounting to $85.7 \%$ of the fermentation theoretical efficiency and ethanol concentration of about $14 \% \mathrm{v} / \mathrm{v}(110 \mathrm{~g} / \mathrm{l})$ were obtained. The starch utilization was $96.7 \%$. Figure 2 presents changes of ethanol, starch and glucose concentrations during the SSF process. The data indicate that the starch hydrolysis was effective and ran parallel to the fermentation process.

According to the data by Genencor International Inc., the application of STARGEN 001 preparation and corn mash in the concentration of $33 \%$ of dry mass enables obtaining final ethanol concentrations of $16-18 \%$. 


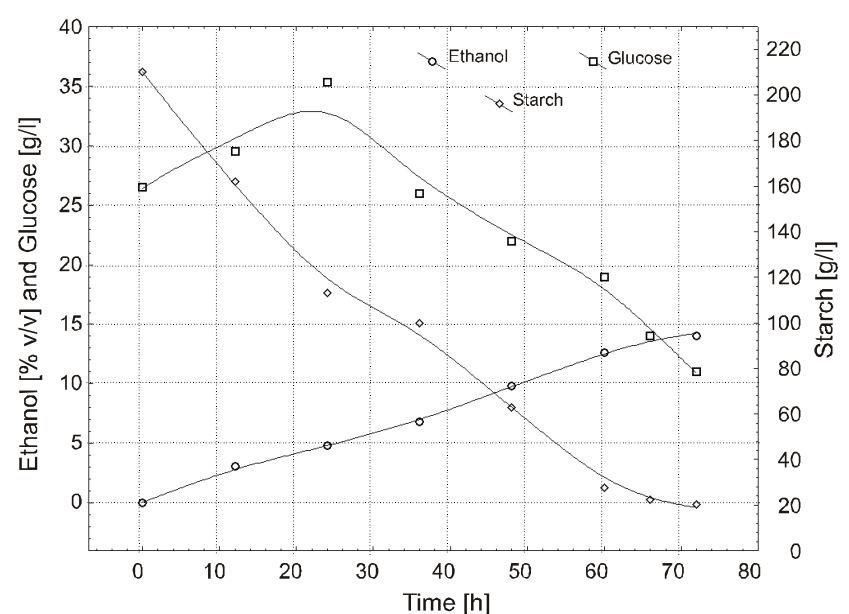

Fig. 2. Changes in starch, glucose and ethanol concentrations during the process of simultaneous starch hydrolysis and ethanol fermentation

These values, however, were not confirmed by any publications or descriptions of really performed production processes. The discrepancies between the obtained results and the values provided by the enzyme manufacturer may result from several reasons. Course of this digestion/fermentation process strongly depends on the quality of the raw material - its origin, species and variety, affecting the shares of particular starch fractions, and also on the flour granulation that determines starch availability to the enzymes.

The data presented by Wang et al. (2000 and 2005) indicate that to liquefy starch by STARGEN 001 preparation, the process of fermentation must run at the temperature of $33^{\circ} \mathrm{C}$ and be preceded by one-hour mash incubation at the temperature of $48^{\circ} \mathrm{C}$ at $\mathrm{pH} 4.2$. Thus, there were significant differences between the conditions applied in Wang's and our experiments. In our experiment STARGEN 001 was added directly together with yeast to the mash of the temperature of $35^{\circ} \mathrm{C}$. In addition, Wang used yeast Saccharomyces cerevisiae from different supplier (Fleischmann's Yeast, Fenton, MO, USA). However, the analysis of the publications that were based on the research using STARGEN 001 preparation reveals that the results of the present study are very similar to those published by Wang et al. (2005). The authors compared the process performed according to STARGEN 001 technology with the traditional process of ethanol production with liquefaction at the temperature of $90-120^{\circ} \mathrm{C}$, then saccharification with the use of two different combinations of liquefying and sac- charifying enzymes (DG1 and DG2; $\alpha$-amylase and glucoamylase), and fermentation. In both methods the authors obtained similar final ethanol concentrations of 14.1$14.2 \%(\mathrm{v} / \mathrm{v})$ with significantly different sugar profiles of the analyzed systems.

Sharma et al. (2007) compared the catalytic efficiency of STARGEN 001 preparation with the activity of traditional amylolytic enzymes. The raw material included starch with various ratios of amylose and amylopectin. The best results were obtained when starch without amylose was used. In this case, the final ethanol concentration $(8.2 \% \mathrm{v} / \mathrm{v})$ was the same regardless STARGEN 001 preparation or traditional enzymes were used. However, for starch with a high content of amylase, higher concentrations of ethanol were obtained with STARGEN 001. Lately Sharma et al. (2010) reported that one can further increase the efficacy of bioethanol production by applying new liquefying enzymes. The obtained ethanol concentrations were $0.54 \%$ higher (v/v) after 72 -hour SSF process than in experiment involving STARGEN 001 only. However, it should be emphasized that each time SSF was preceded with a high-temperature stage $\left(48-90^{\circ} \mathrm{C}\right)$. STARGEN 001 was also used for bioethanol production from barley starch (Gibreel et al. 2009) and the efficiency of this process was similar to the efficiency of corn starch processing.

\section{Simultaneous saccharification of native corn starch and ethanol fermentation (SSF) with stillage recycling}

One of the key factors determining the effectiveness of the conversion of plant biomass to bioethanol is the total costs of this process, including the cost of technological water. In this context, it is worth emphasizing that the water shortage has began a global issue, which leads to the increasing cost of each water-consuming process. This situation affects also Poland, hence the efforts aiming at the reduction of technological water consumption are of great importance. Another factor that is intrinsic to water management is effluent production. Distillery stillage is ranked among especially burdensome industrial effluents particularly at large biorefineries, and its utilization is expensive. One of the methods of lowering the costs of water used by distilleries is reutilization of stillage in the production process. Scientific literature provides a range of suggestions concerning the reutilization of distillery stillage for technological purposes (Kishimoto et al., 1997). However, there are 
Table 1. Time course of SSF processes with stillage recycling (SR) and without stillage recycling (S)

\begin{tabular}{c|c|c|c|c|c|c|c|c}
\hline \multirow{2}{*}{$\begin{array}{c}\text { Time fermentation } \\
{[\mathrm{h}]}\end{array}$} & \multicolumn{2}{|c|}{$\begin{array}{c}\text { Ethanol } \\
{[\mathrm{g} / \mathrm{l}]}\end{array}$} & \multicolumn{2}{c|}{$\begin{array}{c}\text { Starch } \\
{[\mathrm{g} / \mathrm{l}]}\end{array}$} & \multicolumn{2}{c|}{$\begin{array}{c}\text { Glucose }+ \text { Maltose } \\
{[\mathrm{g} / \mathrm{l}]}\end{array}$} & \multicolumn{2}{c}{$\begin{array}{c}\text { Yeast density } \\
{\left[1 \times 10^{8} \mathrm{CFU} \mathrm{ml}^{-1}\right]}\end{array}$} \\
\cline { 2 - 24 } & $\mathrm{SR}$ & $\mathrm{S}$ & $\mathrm{SR}$ & $\mathrm{S}$ & $\mathrm{SR}$ & $\mathrm{S}$ & $\mathrm{SR}$ & $\mathrm{S}$ \\
\hline 0 & 0 & 0 & 218.4 & 208.3 & 23.53 & 23.87 & 1.82 & 1.93 \\
\hline 24 & 35.7 & 39.6 & 123.9 & 167.3 & 10.94 & 18.00 & 1.81 & 1.93 \\
\hline 48 & 77.6 & 85.0 & 70.3 & 78.0 & 8.95 & 7.50 & 1.73 & 1.93 \\
\hline 72 & 91.9 & 95.5 & 37.7 & 32.2 & 8.59 & 3.44 & 1.69 & 1.93 \\
\hline
\end{tabular}

only a few described processes where the whole stillage or its liquid fraction are repeatedly turned back and reutilized to prepare a new batch of medium. So far, the possibility of stillage turning back in the SSF process involving native starch hydrolysis has not been investigated.

As shown in Table 1 minor differences were observed in ethanol concentration when the conventional SSF process $(\mathrm{S})$ and the process with stillage recycling (SR) were compared.

Approximately 3.2\% higher final ethanol concentration was achieved for S process. However, this difference can be regarded as insignificant due to their $p$ value being greater than 0.05 . The same was observed for ethanol productivity. The calculated average value for this parameter for SR process was $1.28 \mathrm{~g} \mathrm{l}^{-1} \mathrm{~h}^{-1}$ and $1.32 \mathrm{~g} \mathrm{l}^{-1} \mathrm{~h}^{-1}$ for $\mathrm{S}$ process, respectively. However, ethanol yields, $\mathrm{Y}_{\mathrm{p} / \mathrm{s}}$ for $\mathrm{SR}$ and $\mathrm{S}$ process were 0.49 and $0.53 \mathrm{~g} / \mathrm{g}$ respectively. This means that the efficiency of starch conversion to ethanol for SR and S system were $87.5 \%$ and $94.6 \%$ of theoretical value, respectively. The F-test analysis of the variance revealed that they were significantly different $(p=0.021)$. Arguably, such differences can be related to the lower count of yeast in the recycled system resulting from the environmental stress which can cause disruption of cellular ionic homeostasis, leading to a reduction of metabolic activity and, eventually, the death of a cell (Table 1).

\section{Effect of stillage recycling on the final ethanol concentration}

In the first place, attention was paid to the changes in the ethanol concentration in the medium, depending on the number of recirculations. The results of the chemical and statistical analyses prove that the process was stable through all the cycles and could have been con- tinued longer (the fermentations were continued in 51 bioreactors with no interruptions until the $30^{\text {th }}$ cycle).

The final ethanol concentration in the process with stillage recycling on average amounted to $91.9 \mathrm{~g} / \mathrm{l}$ (Fig. 3 ). Each subsequent recirculation entailed a slight reduction of the final ethanol concentration on average by $0.01 \%$, however, the regression analysis demonstrated that the changes were statistically insignificant $(p>0.05)$.

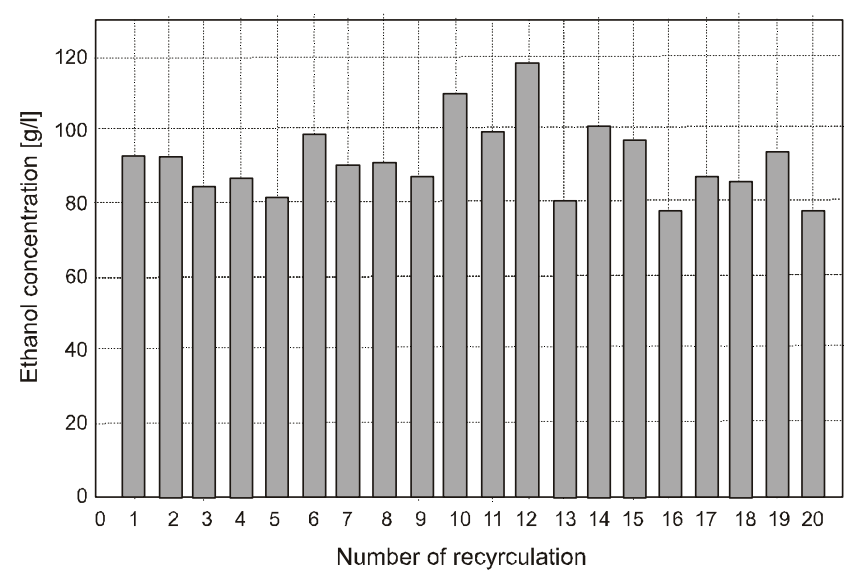

Fig. 3. Effect of stillage recycling on the final ethanol concentration

\section{Effect of stillage recycling on the efficiency of ethanol fermentation}

Changes in the fermentation efficiency were analysed with regard to the number of recirculations. The efficiency of the fermentation process in 51 bioreactors maintained on the constant mean level of $83.74 \%$ of the theoretical fermentation efficiency (Fig. 4). In subsequent recirculations some fluctuations in fermentation efficiency were observed, but they can be assumed as statistically insignificant $(0.31 \% ; p>0.05)$. 


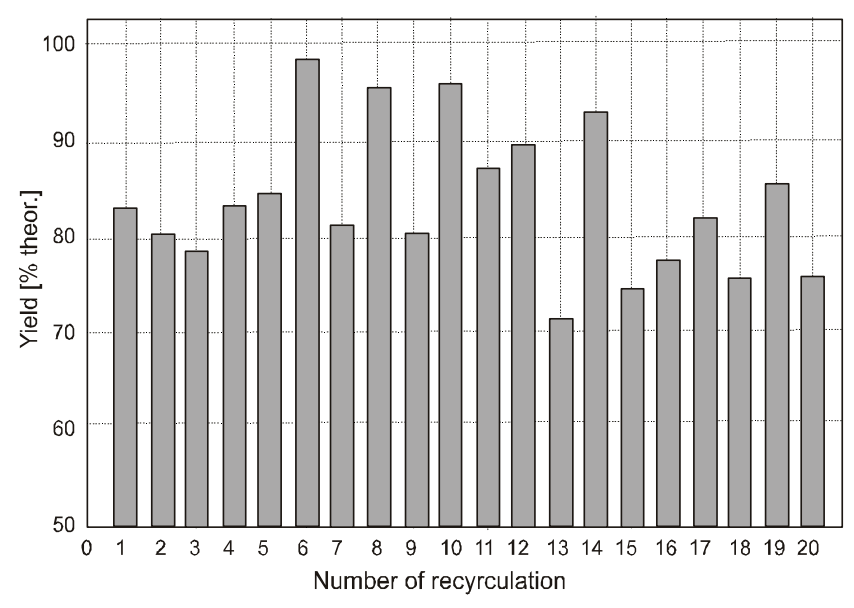

Fig. 4. Effect of stillage recycling on the yield of ethanol fermentation

A technology based on stillage recycling was successfully applied in the laboratory scale for three months. On the basis of material balance, it can be assumed that post-distillation drained liquid, replaced $75-80 \%$ of the technological water necessary for preparing starch mash. However, Navarro et al. (2000) observed the reverse correlation between final ethanol concentration in fermented wort and the number of recirculations. The former changed from 6.5 to $1.8 \% \mathrm{v} / \mathrm{v}$. The authors assumed the accumulation of fermentation by-products (glycerol, lactic acid, propanol) hinders normal yeast metabolism. The results obtained in this study suggested that drastic changes in the ethanol concentration could not be associated with stillage recycling. Lalov et al. (2000) suggested that stillage dilution with water would solve this problem. Such efforts increased the ethanol concentration to $7 \% \mathrm{v} / \mathrm{v}(5.23 \% \mathrm{w} / \mathrm{v})$ during 14 recirculations. The same authors described a method of side metabolite removal (salts, acids) with the use of electrodialysis. Chitosan, can also be used as an ion exchanger which eliminates all acids from the culture medium and increases $\mathrm{pH}$. Kishimoto et al. (1997) presented a bioreactor integrated with the distillation column where stillage that left the column was recycled to the bioreactor. The experiment was conducted for 500 hours without any complications and included 56 distillations with the mean theoretical efficiency of the process amounting to $92 \%$. After finishing the experiment, the effluent volume amounted to $6 \%$ of the volume of the effluent originating from the traditional technology. After 500 hours the process was halted since its effectiveness started to lower. This was most likely caused by the elevated accu- mulation of glycerol and lactic acid in cells as well as by the formation and accumulation of Maillard reaction products (in the distillation column). Ohashi et al. (1998) increased the density of cells in the medium by using a ceramic filter that kept the cells in the bioreactor during stillage recirculation. As a result, both cell density and process productivity amounted up to $236 \mathrm{~g} / \mathrm{l}$ and $13.1 \mathrm{~g} \mathrm{l}^{-1} \mathrm{~h}^{-1}$, respectively. However, it was the microfilter blocking that turned out to be a problem in that case. The impediment was overcome with yeast immobilization in calcium alginate, which resulted in the increase of volume productivity to $14.5 \mathrm{~g} \mathrm{l}^{-1} \mathrm{~h}^{-1}$, even though those solutions did not reach beyond the laboratory scale. For comparison, the Nicolic's team (2009) obtained volume productivity amounting to $1.96 \mathrm{~g} \mathrm{l}^{-1} \mathrm{~h}^{-1}$ after 48 hours of the SSF process with the use of gelatinized corn starch (without stillage recirculation) and immobilized cells of Saccharomyces cerevisiae var. ellipsoideus.

Couallier and coworkers suggested that the application of nanofiltration or reverse osmosis can reduce the content of organic compounds in stillage by $99 \%$ (Couallier et al., 2008). The filtrate obtained in the process showed a very low chemical oxygen demand index, which allows to reuse it not only during the subsequent fermentation, but also to maintain the work of other technological devices, such as steam generators or CIP (cleaning-inplace) cleaning systems. However, the discussed system has some severe limitations. The use of membrane filtration techniques requires filtrated medium clarification before separation on NF (nanofiltration) or RO (reverse osmosis) membranes. Too high content of the insoluble fraction may lead to irreparable damages to the filtration modules and contribute, thereby, to increased costs.

The above-described methods of water recycling from the distillery stillage were used in the traditional technology of ethanol production, when starch was subjected to the process of gelatinization, followed by hydrolysis at about $60^{\circ} \mathrm{C}$. However, there are no reports on the using of membrane techniques in the process of stillage recirculation after the simultaneous hydrolysis and fermentation (SSF) of native starch.

\section{Conclusions}

Here we demonstrated that the developed technology enables an effective bioethanol production. The final ethanol concentration was about $11 \%(\mathrm{v} / \mathrm{v})$, practical 
fermentation efficiency amounted to about $84 \%$ of the theoretical efficiency and starch utilization was over $90 \%$.

Additionally, we showed that the application of the developed technology can: (i) reduce technological water consumption by more than $80 \%$; (ii) drastically decrease the amount of post-production wastewater and (iii) partly reduce the energy consumption in the production process.

\section{References}

Bednarski W., Reps A. (2003) Biotechnologia żywności. Wydawnictwa Naukowo-Techniczne. Warszawa.

Białas W., Wojciechowska D., Szymanowska D., Grajek W. (2009) Optymalizacja procesu jednoczesnej hydrolizy ifermentacji natywnejskrobi metodą powierzchniodpowiedzi. Biotechnol. 87: 183-199.

Decloux M., Boriesb A., Lewandowski R., Fargues C., Mersad A., Laure Lameloisea M., Bonnet F., Dherbecourt B., Osuna L.N. (2002) Interest of electrodialysis to reduce potassium level in vinasses. Preliminary experiments. Desalination 146: 393-398.

Erdei B., Barta Z., Sipos B., Réczey K., Galbe M., Zacchi G. (2010) Ethanol production from mixtures of wheat straw and wheat meal. Biotech. Bio. 3: 16-19.

Fitzgibbon F., Nigam P., Singh D., Archant R. (1995) Biological treatment of distillery waste for pollution-remediation. J. Basic Microbiol. 35: 239.

Gibreel A., Sandercock J.R., Lan J., Goonewardene L.A., Zijlstra R.T., Curtis J.M., Bressler D.C. (2009) Fermentation of barley by using Saccharomyces cerevisiae: examination of barley as a feedstock for bioethanol production and valueadded products. Appl. Env. Microbiol. 75 (5): 1363-1372.

Holm J., Björck I., Drews A., Asp N.G. (1986) A rapid method for the analysis of starch. Starch/Stärke. 38: 224-226.

Kishimoto M., Nitta Y., Kamoshita Y., Suzuki T., Suga K.I. (1997) Ethanol production in an immobilized cell reactor coupled with the recycling of effluent from the bottom of a distillation column. J. Ferment. Bioeng. 84: 449-454.

Kobayashi F., Sawada T., Nakamura Y., Ohnaga M., Godliving M., Ushiyama T. (1998) Saccharification and alcohol fermentation in starch solution of steam-exploded potato. Biotechnol. Appl. Biochem. 69: 177-189.

Lalov I.G., Guerginov I.I., Krysteva M.A., Fartsov K. (2000) Treatment of waste water from distilleries with chitosan. Water Res. 34:1503-1506.

Lim L.H., Macdonald D.G., Hill G.A. (2003) Hydrolysis of starch particles using immobilized barley [alpha]-amylase. Biochem. Eng. J. 13: 53-62.
Madejon E., Diaz M.J., Lopez R., Cabrera F. (2001) Co-composting of sugarbeet vinasse: Influence of the organic matter nature of the bulk agents used. Bioresource Technol. 76: 275-278.

Morin Couallier E., Fargues C., Lewandowski R., Decloux M., Lameloise M.L. (2008) Reducing water consumption in beet distilleries by recycling the condensates to the fermentation phase. J. Clean Prod. 16: 655-663.

Navarro A.R., Sepulveda M., Del C., Rubio M.C. (2000) Bioconcentration of vinasse from the alcoholic fermentation of sugar cane molasses. Waste Management 20: 581-585.

Nicolic S., Mojović L., Rakin M., Pejin D. (2009) Bioethanol production from corn meal by simultaneous enzymatic saccharification and fermentation with immobilized cells of Saccharomyces cerevisiae var ellipsoideus. Fuel 88: 1602-1607.

Ohashi R., Kamoshita Y., Kishimoto M., Suzuki T. (1998) Continuous production and separation of ethanol without effluence of wastewater using integrated SCM-reactor system. J. Ferment. Bioeng. 86: 220-225.

Öhgren K., Bura R., Lesnicki G., Saddler J., Zacchi G. (2007) A comparison between simultaneous saccharification and fermentation and separate hydrolysis and fermentation using steam-pretreated corn stover. Process Biochem. 42(5): 835-839.

Shanavas S., Padmaja G., Moorthy S.N., Sajeew M.S., Sheriff J.T. (2011) Process optimization for bioethanol production from cassava starch using novel eco-friendly enzymes. Biomass Bioener. 35: 901-909.

Sharma V., Singh V., Rausch K.D., Tumbleson M.E. (2007) Comparison between granular starch hydrolyzing enzyme and conventional enzymes for ethanol production from maize starch with different amylose: amylopectin ratios. Starch/Stärke 59(11): 549-556.

Sharma V., Rausch K.D., Graeber J.V., Schmidt S.J., Buriak P., Tumbleson M.E., Singh V. (2010) Effect of resistant starch on hydrolysis and fermentation of corn starch for ethanol. Appl. Biochem. Biotechnol. 160(3): 800-811.

Thomsen M.H., Holmn-Nielsen J.B., Olesowicz-Popiel P., Thomsen A.B. (2008) Pretreatment of whole-crop harvested, ensiled maize for ethanol production. Appl. Biochem. Biotechnol. 148: 23-33.

Wang J., Liu W., Uno T., Tonozuka H., Mitsui K., Tsurugi K. (2000) Cellular stress responses oscillate in synchronization with the ultradian oscillation of energy metabolism in the yeast Saccharomyces cerevisiae. FEMS Microbiol. Lett. 189: 9-13.

Wang P., Singh V., Xu L., Rausch K.D., Tumbleson M.E., Johnston D.B. (2005) Comparison of enzymatic (E-Mill) and conventional dry-grind corn processes using a granular starch hydrolyzing enzyme. Cereal Chem. 82: 734-738. 